\section{Response of Poinsettia to Preplant Root-zone Soaks in Uniconazole}

\author{
Bradford C. Bearce ${ }^{1}$ and Suman Singha ${ }^{1,2}$ \\ Division of Plant and Soil Sciences, West Virginia University, \\ Morgantown, WV 26506-6108
}

Additional index words. Euphorbia pulcherrima, XE-1019, Rootcube

Current methods of growth retardant application, such as root-zone drenches and topical sprays, may lack precision of dosage and thus accuracy of plant height control (Tayama, 1990). Bulb soaks, as used by Bearce and Singha (1990) and by McDaniel (1990), have the advantage of restricting application of growth retardant to the plant material and can be performed before placing plants in the growing environment. The objective of the present study was to evaluate preplant root-zone soaks in uniconazole as a method for achieving height control in poinsettia plants.

'Brilliant Diamond' poinsettia (Euphorbia pulcherrima Willd. ex Kl.) cuttings rooted in Oasis Rootcube Strips (Smithers-Oasis, Kent, Ohio) were received 26 July 1988 and placed under $50 \%$ shade in a greenhouse at 29/16C and immediately irrigated. Plants were divided into two groups of 32 plants each, with one group receiving a second irrigation just before uniconazole treatment ( $36 \mathrm{~h}$ later). Preplant root-zone treatments were applied by soaking Rootcubes for 15 min to a depth of $2.5 \mathrm{~cm}$ in a 1.5-liter solution of $0,0.1$, 1.0 , or $10 \mathrm{mg}$ uniconazole/liter. Volume of solution absorbed by Rootcubes was recorded by weighing each before and after soaking. Cubes were then allowed to drain for $30 \mathrm{~min}$, and plants were individually planted in 1.8 -liter $(15-\mathrm{cm})$ plastic pots in a commercial peat, vermiculite, and perlite mix (Sunshine Mix, Fison, Vancouver, B.C.) and placed in full light in the greenhouse. There were eight single plants per treatment, with pots placed in a completely randomized arrangement on the bench.

Plants were fertilized weekly with $2.3 \mathrm{~g}$ of a soluble $0.15 \mathrm{~N}-0.088 \mathrm{P}-0.22 \mathrm{~K}$ fertilizer/ liter plus $0.28 \mathrm{mg} \mathrm{Na} \mathrm{MoO}_{4} /$ liter. On 24 Aug., plants were pinched to a height of seven

Received for publication 27 Mar. 1992. Accepted for publication 30 June 1992. Approved for publication by the Director, West Virginia Agr. and For. Expt. Sta. as Scientific Article no. 2308. We thank Valent USA Corp. for providing uniconazole. The cost of publishing this paper was defrayed in part by the payment of page charges. Under postal regulations, this paper therefore must be hereby marked advertisement solely to indicate this fact.

${ }^{1}$ Professor of horticulture.

${ }^{2}$ Present address: Dept. of Plant Science, Univ. of Connecticut, Storrs, CT 06269-4067. a scale of 5 to 0 , best to worst. to eight nodes and spaced $30 \mathrm{~cm}$ apart. Plant height was measured on 29 Nov. from the soil line to the highest point on each plant. The number of bract clusters on the outside of each plant was counted, and bract cluster diameter was recorded as the mean of the widest diameters of the largest cluster on each plant. The study was repeated in 1989. Procedures used were the same as those followed during the first trial, except that Rootcubes were soaked in water and allowed to drain for $10 \mathrm{~min}$ before treatment with uniconazole. Also, a plant quality comparison based on extent of bract cluster maturity, bract cluster display and brightness, plant symmetry, and leaf color was performed. Data were subjected to analysis of variance with single-degree-of-freedom contrasts.

Preplant root-zone soak in uniconazole reduced plant height and bract cluster count and diameter; the reduction was most pronounced with the highest concentrations of uniconazole (Table 1). Reduction in growth and flowering was greater in plants irrigated $36 \mathrm{~h}$ before treatment with uniconazole than in plants irrigated just before treatment. Re- duction in bract size was especially pronounced at $10 \mathrm{mg} \cdot$ liter $^{-1}$.

Mean uniconazole solution uptake per Rootcube was significantly greater $(19.8 \mathrm{ml})$ when plants were not irrigated for $36 \mathrm{~h}$ before treatment than when irrigated immediately before treatment $(10.5 \mathrm{ml})$. The increased growth reduction by uniconazole with the 36-h treatment is attributed to the increased per-plant dosage. Thus, both the concentration of the growth retardant and the volume of uptake into the Rootcube influenced the extent of growth suppression. To achieve a predictable response, it is important that Rootcubes have a defined water content.

The 1989 crop response was similar to that obtained in 1988. Overall plant quality ratings were especially low at the higher uniconazole levels (Table 1). These results indicate that preplant root-zone soaks have potential as an effective method of applying growth retardants. Careful regulation of growth retardant concentration and volume of solutions taken up by root zones is necessary to achieve desired height reduction without excess reduction of bract cluster count and size.

\section{Literature Cited}

Bearce, B.C. and S. Singha. 1990. Growth and flowering response of Asiatic hybrid lilies to uniconazole. HortScience 25:1307.

McDaniel, G. 1990. Postharvest height suppression of potted tulips with paclobutrazol. HortScience 25:212-214.

Tayama, H.K. 1990. Chemical growth regulators-problems, causes and recommendations. Ohio Florists Assn. Bul. 724:3-4.

Table 1. Effect of preplant root-zone soaks of uniconazole on plant height and number and size of bract clusters of 'Brilliant Diamond' poinsettias (1988 crop).

\begin{tabular}{|c|c|c|c|c|}
\hline $\begin{array}{l}\text { Uniconazole } \\
\text { concn } \\
\text { (mg-liter }{ }^{-1} \text { ) }\end{array}$ & $\begin{array}{l}\text { Plant ht } \\
\text { (cm) }\end{array}$ & $\begin{array}{l}\text { Bract } \\
\text { clusters } \\
\text { (no.) }\end{array}$ & $\begin{array}{c}\text { Bract } \\
\text { cluster } \\
\text { diam } \\
(\mathrm{cm})\end{array}$ & $\begin{array}{c}\text { Quality } \\
\text { rating }^{2} \\
\text { (1989 crop) }\end{array}$ \\
\hline \multicolumn{5}{|c|}{ Rootcubes irrigated $0 \mathrm{~h}$ before treatment } \\
\hline 0 & 32.3 & 8.3 & 22.0 & 3.8 \\
\hline 0.1 & 31.3 & 7.8 & 25.5 & 3.6 \\
\hline 1.0 & 20.8 & 5.5 & 20.9 & 2.0 \\
\hline 10.0 & 12.1 & 3.0 & 15.3 & 1.0 \\
\hline \multicolumn{5}{|c|}{ Rootcubes irrigated $36 \mathrm{~h}$ before treatment } \\
\hline 0 & 31.4 & 5.1 & 24.0 & \\
\hline 0.1 & 21.4 & 6.1 & 22.4 & \\
\hline 1.0 & 16.4 & 4.8 & 20.0 & \\
\hline 10.0 & 13.6 & 2.8 & 11.2 & \\
\hline Controly vs. $0 \mathrm{~h}$ & $* *$ & $*$ & $*$ & ** \\
\hline Controly vs. $36 \mathrm{~h}$ & $* *$ & NS & $* *$ & \\
\hline \multirow{2}{*}{\multicolumn{5}{|c|}{$0 \mathrm{~h}$}} \\
\hline & & & & \\
\hline Linear & ** & ** & $* *$ & ** \\
\hline Quadratic & $* *$ & $* *$ & $*$ & $* *$ \\
\hline \multicolumn{5}{|l|}{$36 \mathrm{~h}$} \\
\hline Linear & ** & ** & ** & \\
\hline Quadratic & ** & ** & * & \\
\hline
\end{tabular}

${ }^{z}$ Plants were rated for flower maturity, bract display and brightness, plant symmetry, and leaf color on

${ }^{\mathrm{y}}$ Control refers to the 0 uniconazole concentration in the specified irrigation regime.

NS ${ }^{*}, * *$ Contrast or treatment nonsignificant or significant at $P=0.05$ or 0.01 , respectively. 